\title{
ACTIVATION OF PROTEIN KINASE C INHIBITS NaF-INDUCED INOSITOLPHOSPHOLIPID TURNOVER IN ISOLATED CANINE PARIETAL CELLS
}

\author{
Tsutomu Chiba ${ }^{1}$, Akira Nakamura ${ }^{1}$, Toshiyuki Yamatani ${ }^{2}$ and Takuo Fujita ${ }^{2}$ \\ ${ }^{1}$ Division of Gerontology, and ${ }^{2}$ Third Division, Department of Internal Medicine, Kobe University School of Medicine, Kobe 650 , \\ Japan
}

\begin{abstract}
Effects of protein kinase $\mathrm{C}$ (PKC) activation by 12-O-tetradecanoylphorbol-13-acetate (TPA) on $\mathrm{NaF}$-induced inositolphospholipid metabolism were investigated in canine parietal cells. $\mathrm{NaF}$ dose-dependently stimulated the formation of $\left[{ }^{3} \mathrm{H}\right]$ inositolphosphates, which was characterized by a rapid generation of $\left[{ }^{3} \mathrm{H}\right]$ inositoltrisphosphate $\left(\mathrm{IP}_{3}\right)$ within 3 min. Furthermore, NaF elicited a rapid decrease in ${ }^{32} \mathrm{P}$-labeling of phosphatidylinositol-4,5-bisphosphate $\left(\mathrm{PIP}_{2}\right)$ with a simultaneous increase in $\left[{ }^{32} \mathrm{P}\right]$ phosphatidic acid (PA). Although TPA alone had no effect, it significantly inhibited the inositolphospholipid turnover enhanced by NaF. Since $\mathrm{NaF}$ is known to directly activate guanine nucleotide binding proteins ( $\mathrm{G}$ proteins), $\mathrm{PKC}$ activation appears to inhibit inositolphospholipid turnover at a level between a $G$ protein and phospholipase C-induced $\mathrm{PIP}_{2}$ breakdown.
\end{abstract}

We have previously demonstrated that two acid secretagogues, carbachol and gastrin, stimulate inositolphospholipid turnover followed by translocation of protein kinase $\mathrm{C}$ (PKC) activity from the cytosol to membranes $(6,7)$. In addition to the stimulation of acid secretion by carbachol and gastrin, PKC activation is also involved in the mechanism that inhibits a signal transduction in canine parietal cells by attenuating inositolphospholipid turnover, indicating that this inhibition is at least partly due to down-regulation of muscarinic and gastrin receptors (6). However, accumulating evidence also suggests that PKC exerts an inhibitory action on receptor-stimulated inositolphospholipid turnover at more than one site $(4,5,18)$.

On the other hand, recent studies have indicated that $\mathrm{NaF}$ can directly activate various $\mathrm{G}$ proteins including the one involved in phospholipase $\mathrm{C}$ activation with resultant phosphatidylinositol-4,5-bisphosphate $\left(\mathrm{PIP}_{2}\right)$ breakdown $(3,9,13,17)$. Thus, by using $\mathrm{NaF}$, it is possible to activate the intracellular signal transduction system without involving the receptor. The present study was undertaken to examine whether the activation of PKC also exerts an inhibitory action on canine parietal cells at a level distal to receptor activation upon agonist binding.

\section{MATERIALS AND METHODS}

Mucosal cells were dispersed from stripped canine fundus by sequential exposure to collagenase $(0.35$ $\mathrm{mg} / \mathrm{ml}$ ) and ethylene-diaminetetra-acetic acid (EDTA, $1 \mathrm{mM}$ ), and parietal cells were further enriched by centrifugal elutriation $(7,16)$.

To measure the formation of inositolphosphates, cells $\left(4 \times 10^{6}\right)$ were preincubated for $2 \mathrm{~h}$ at $37^{\circ} \mathrm{C}$ in $0.4 \mathrm{ml}$ of HEPES-buffered Krebs-Ringer bicarbonate buffer, $1 \mathrm{mg} / \mathrm{ml}$ bovine serum albumin and 5.6 $\mathrm{mM}$ D-glucose, $\mathrm{pH} 7.4$ (HKRBG), containing $5 \mu \mathrm{Ci}$ $\left[{ }^{3} \mathrm{H}\right]$ inositol (Amersham, Arlington Heights, IL, U.S.A.). At $110 \mathrm{~min}$ of incubation, lithium chloride was added to a final concentration of $10 \mathrm{mM}$. Further incubation was then initiated by adding various test agents $(100 \mu 1)$, and after $30 \mathrm{~min}$ the incubation was terminated by adding $1.5 \mathrm{ml}$ of chloroform:methanol $(1: 2)$. Water-soluble inositolphosphates were separated from $\left[{ }^{3} \mathrm{H}\right]$ insitol by 
ion-exchange chromatography as described by Berridge et al. (2). In some experiments, cells were prelabeled with $\left[{ }^{3} \mathrm{H}\right]$ inositol for $4 \mathrm{~h}$ and incubated under test conditions for $3 \mathrm{~min}$. The aqueous products were then separated on a Dowex-1 column into inositolmonophosphate (IP), inositolbisphosphate $\left(\mathrm{IP}_{2}\right)$, inositoltrisphosphate $\left(\mathrm{IP}_{3}\right)$, and inositoltetrakisphosphate $\left(\mathrm{IP}_{4}\right)(1,7)$.

In the ${ }^{32} \mathrm{P}$-labeling experiment, parietal cells $\left(100 \times 10^{6}\right)$ were preincubated for $2 \mathrm{~h}$ at $37^{\circ} \mathrm{C}$ in 10 $\mathrm{ml}$ of phosphate-free buffer $(142 \mathrm{mM} \mathrm{NaCl}, 5.6$ $\mathrm{mM} \mathrm{KCl}, 2.2 \mathrm{mM} \mathrm{CaCl}_{2}, 3.6 \mathrm{mM} \mathrm{NaHCO}_{3}, 1 \mathrm{mM}$ $\mathrm{MgCl}_{2}, 5.6 \mathrm{mM}$-glucose and $30 \mathrm{mM}$ HEPES, $\mathrm{pH}$ 7.4) containing $1 \mathrm{mCi}\left[{ }^{32} \mathrm{P}\right]$ orthophosphate. Cells were then washed three times and resuspended in phosphate-free buffer. Aliquots $(400 \mu 1)$ of the cell suspension $\left(4 \times 10^{6}\right.$ cells) were added to $100 \mu 1$ of phosphate-free buffer with or without $\mathrm{NaF}$ (final concentration, $20 \mathrm{mM}$ ) and incubated for various periods at $37^{\circ} \mathrm{C}$. The reaction was terminated by adding $1.5 \mathrm{ml}$ of chloroform: methanol $(1: 2)$, and phospholipids were extracted (15), and separated by TLC using chloroform:methanol:acetone:acetic acid: water $(40: 14: 13: 12: 8)$ as a solvent (10). To measure de novo synthesis of phospholipids, cells were incubated in phosphate-free buffer containing both test substances and $\left[{ }^{32} \mathrm{P}\right]$ orthophosphate ( $5 \mu \mathrm{Ci} / 2 \times 10^{6}$ cells) for $20 \mathrm{~min}$, and phospholipids were then extracted and separated as described above.

For the measurement of cyclic AMP production, cells $\left(10^{6}\right)$ were preincubated in $0.9 \mathrm{ml}$ of HKRBG for $10 \mathrm{~min}$ at $37^{\circ} \mathrm{C}$, various test materials $(100 \mu \mathrm{l})$ were then added, and the incubation continued for another $10 \mathrm{~min}$. Cyclic AMP produced was extracted and measured as described previously (8).

\section{RESULTS AND DISCUSSION}

$\mathrm{NaF}$ significantly and dose-dependently increased the formation of $\left[{ }^{3} \mathrm{H}\right]$ inositolphosphates in parietal cells at concentrations ranging from 2 to $20 \mathrm{mM}$ (Fig. 1). The maximum increase in $\left[{ }^{3} \mathrm{H}\right]$ inositolphosphate formation induced by $20 \mathrm{mM} \mathrm{NaF}$ was $278 \pm 21 \%$ of the basal value, which was higher than the increase produced by $10^{-4} \mathrm{M}$ carbachol and $10^{-6} \mathrm{M}$ pentagastrin (Table 1). Detailed analysis of the inositolphosphates by Dowex column chromatography showed a significant and rapid increase in labeled $\mathrm{IP}_{3}$ and $\mathrm{IP}_{2}$ within $3 \mathrm{~min}$ of incubation upon exposure to $20 \mathrm{mM} \mathrm{NaF}$ (Table 2). Moreover, $\mathrm{NaF}(10 \mathrm{mM})$ elicited a time-dependent increase in

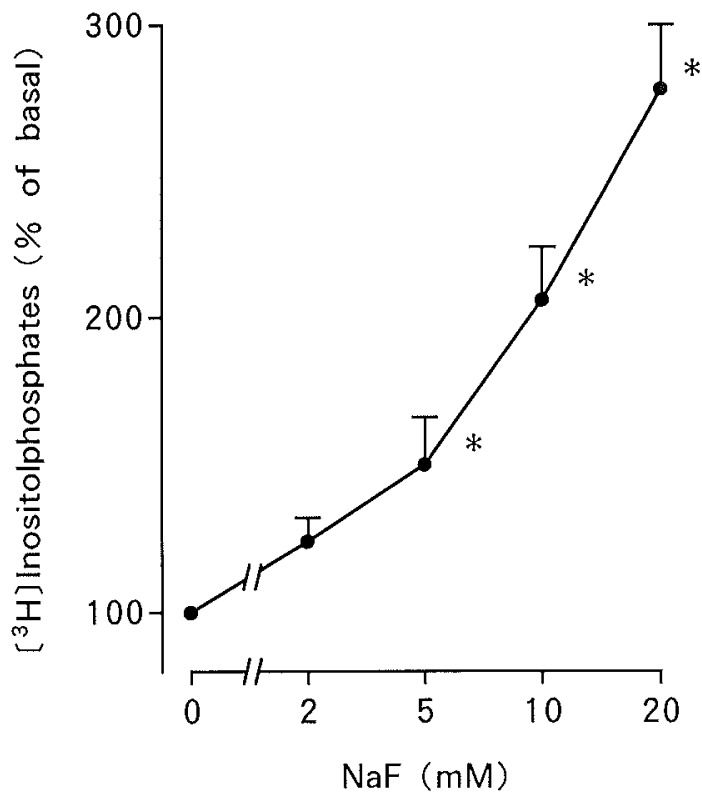

Fig. 1 Effects of $\mathrm{NaF}$ on the production of $\left[{ }^{3} \mathrm{H}\right]$ inositolphosphates in canine parietal cells. Cells $\left(4 \times 10^{6}\right)$ were incubated for $30 \mathrm{~min}$ in $0.5 \mathrm{ml} \mathrm{HKRBG}$ with or without $\mathrm{NaF}$. Values are presented as means \pm SEM from four separate experiments and are expressed as percentages of the control value. Each experiment consisted of triplicate samples. ${ }^{*} P<0.01$ vs control

Table 1 Effects of TPA $\left(10^{-7} \mathrm{M}\right)$ on NaF-, Carbacholand Pentagastrin-Induced Increase in [ $\left.{ }^{3} H\right]$ Inositolphosphate Production in Parietal Cells

\begin{tabular}{|c|c|c|c|}
\hline \multirow{2}{*}{ Agents } & \multicolumn{2}{|c|}{ TPA $\left(10^{-7} \mathrm{M}\right)$} & \multirow{2}{*}{$\begin{array}{c}\% \text { Inhibition } \\
\text { by TPA }\end{array}$} \\
\hline & $(-)$ & $(+)$ & \\
\hline $\mathrm{NaF}$ & $278 \pm 2$ & $3 \pm 19^{* * *}$ & 23 \\
\hline Carbachol $\left(10^{-4} \mathrm{M}\right)$ & $236 \pm 20^{*}$ & $136 \pm 12^{* * *}$ & 42.4 \\
\hline Pentagastrin $\left(10^{-6} \mathrm{M}\right.$ & $218 \pm 28^{*}$ & $133 \pm 14^{* * *}$ & 39.0 \\
\hline
\end{tabular}

After preincubation in the presence or absence of TPA $\left(10^{-7} \mathrm{M}\right)$ for $2 \mathrm{~h}$, parietal cells were incubated for $30 \mathrm{~min}$ with respective test agents. Data represents means \pm SEM from four separate cell preparations and are expressed as percentages of the control (no stimulant and without TPA pretreatment). Each experiment was done in triplicate. ${ }^{*} P<0.01$ vs control; ${ }^{* * *} P<0.01$ vs respective values without TPA pretreatment.

${ }^{32} \mathrm{P}$-labeling of $\left[{ }^{32} \mathrm{P}\right]$ phosphatidic acid (PA) with a concomitant decrease in $\mathrm{PIP}_{2}$-labeling that began as early as $10 \mathrm{sec}$ of incubation (Fig. 2). In contrast, although histamine $\left(10^{-4} \mathrm{M}\right)$ significantly increased cyclic AMP production in parietal cells, 
Table 2 Effects of $\mathrm{NaF}(20 \mathrm{mM})$ on the Production of IP, $\mathrm{IP}_{2}, \mathrm{IP}_{3}$ and $\mathrm{IP}_{4}$ in Canine Parietal Cells

\begin{tabular}{lcccc}
\hline & $\mathrm{IP}$ & \multicolumn{1}{c}{$\mathrm{IP}_{2}$} & \multicolumn{1}{c}{$\mathrm{IP}_{3}$} & $\mathrm{IP}_{4}$ \\
\hline Control & $965 \pm 102$ & $288 \pm 43$ & $168 \pm 28$ & $102 \pm 18$ \\
$\mathrm{NaF}(20 \mathrm{mM})$ & $1,125 \pm 156$ & $422 \pm 46^{*}$ & $362 \pm 34^{*}$ & $130 \pm 21$ \\
\hline
\end{tabular}

After prelabeling with $\left[{ }^{3} \mathrm{H}\right]$ inositol for $2 \mathrm{~h}$, the cells were incubated with or without $\mathrm{NaF}(20 \mathrm{mM})$ for $3 \mathrm{~min}$. Values represent means \pm SEM from four separate experiments and are expressed as dpm $/ 4 \times 10^{6}$ cells. Each experiment was done in triplicate. ${ }^{*} P<0.01$ vs respective control values

$\mathrm{NaF}$ at concentrations between 2 and $20 \mathrm{mM}$ did not influence cyclic AMP content (data not shown). These findings clearly indicate that $\mathrm{NaF}$ activates membrane phospholipase $\mathrm{C}$ in canine parietal cells, which results in a rapid breakdown of $\mathrm{PIP}_{2}$ and production of $\mathrm{IP}_{3}$. Since $\mathrm{NaF}$ has been reported to directly activate certain $\mathrm{G}$ proteins involved in phospholipase $\mathrm{C}$ activation in various cells $(3,9,13,17)$, it appears that $\mathrm{NaF}$ activates a $\mathrm{G}$ protein linked with phosphodiesteratic cleavage of polyphosphoinositide in canine parietal cells.

In a previous study, we found that activation of $\mathrm{PKC}$ by 12-O-tetradecanoylphorbol-13-acetate (TPA) attenuated not only carbachol- but also gastrin-induced polyphosphoinositide breakdown by down-regulating muscarinic and gastrin receptors in parietal cells (6). To examine whether the activation of PKC inhibits inositolphospholipid turnover via a mechanism other than receptor down-regulation, we investigated the effect of activation of PKC by TPA on NaF-induced polyphosphoinositide breakdown. Although TPA $\left(10^{-9}-10^{-7} \mathrm{M}\right)$ alone had no effect on inositolphospholipid turnover (data not shown), it significantly and dose-dependently inhibited the $\mathrm{NaF}(20 \mathrm{mM})$-induced increase in $\left[{ }^{3} \mathrm{H}\right]$ inositolphosphate formation (Fig. 3). Moreover, TPA $\left(10^{-7} \mathrm{M}\right)$ reduced the $\mathrm{NaF}(10$ $\mathrm{mM}$ )-induced increase in de novo $\left[{ }^{32} \mathrm{P}\right] \mathrm{PA}$ synthesis, although $4 \beta$-phorbol $\left(10^{-7} \mathrm{M}\right)$, a phorbol compound with no tumor-promoting activity, had no effect (Fig. 4). These results strongly suggest that, in addition to receptor down-regulation, PKC activation inhibits in parietal cells one of the steps between $\mathrm{G}$ protein activation and polyphosphoinositide hydrolysis. In agreement with our study, Vicentini et al. (18) reported that PKC activation inhibits muscarinic-mediated polyphosphoinositide hydrolysis without altering the binding charac-

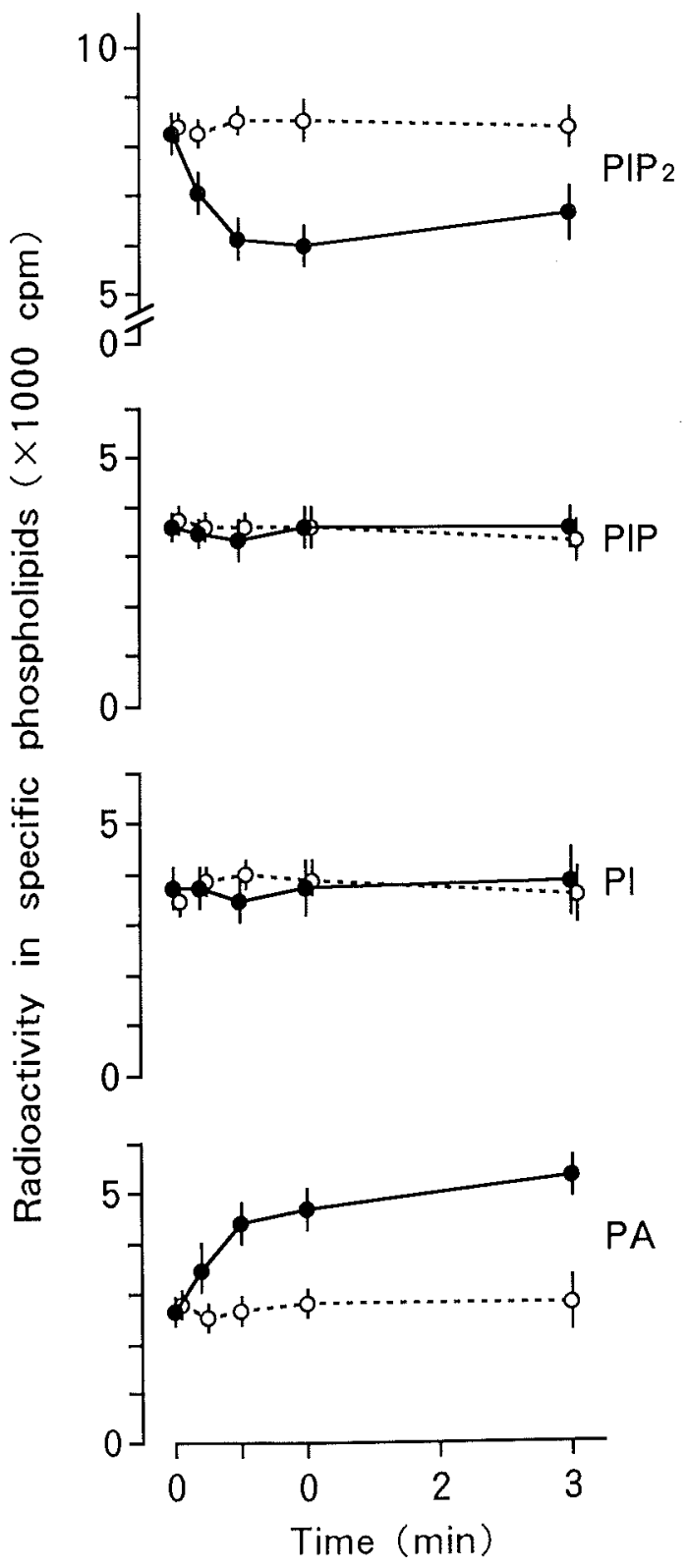

Fig. 2 Effects of $\mathrm{NaF}(10 \mathrm{mM})$ on phospholipid labeling in canine parietal cells. Cells were prelabeled with $\left[{ }^{32} \mathrm{P}\right]$ orthophosphate $\left(40 \mu \mathrm{Ci} / 4 \times 10^{6}\right.$ cells $)$ for $2 \mathrm{~h}$ in phosphate-free buffer. After preincubation, cells were further incubated in $0.5 \mathrm{ml}$ phosphate-free buffer with $(\bullet)$ or without $\left(\mathrm{O}^{--} \mathrm{-}\right) 10 \mathrm{mM} \mathrm{NaF}$ for indicated periods. Each value represents the mean \pm SEM from three separate experiments, and each experiment was performed in duplicate.

teristics of the receptors in PC12 cells, suggesting that PKC activation interferes with the intracellular signal transduction event distal to receptor acti- 


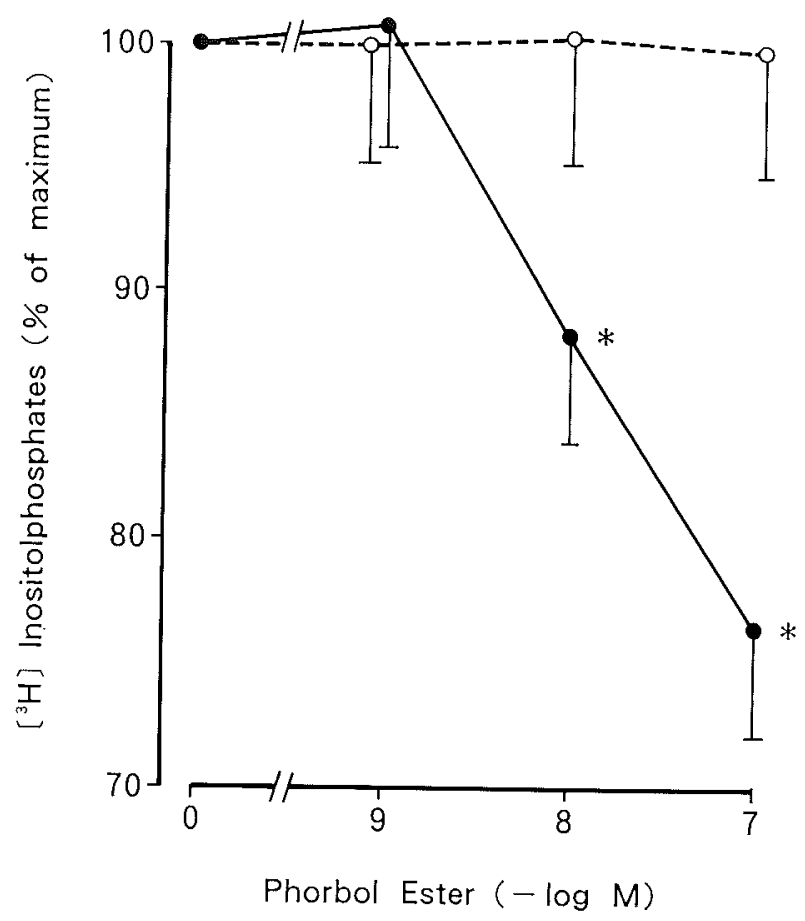

Fig. 3 Effects of TPA and $4 \beta$-phorbol on $\mathrm{NaF}$ $(20 \mathrm{mM})$-induced increase in $\left[{ }^{3} \mathrm{H}\right]$ inositolphosphate production in canine parietal cells. After preincubation in the presence or absence of various concentrations of TPA $(\bullet-\bullet)$ or $4 \beta$-phorbol $(0--\bigcirc)$, parietal cells were incubated with $\mathrm{NaF}(20 \mathrm{mM})$ for $30 \mathrm{~min}$. Data are means \pm SEM from four separate experiments, and are expressed as percentages of the control value obtained with $\mathrm{NaF}$ alone. ${ }^{*} P<0.01$ vs control (without TPA or $4 \beta$ phorbol pretreatment)

vation (14). In this regard, it may be important to note that only a $23.4 \%$ reduction in $\mathrm{NaF}$-induced $\left[{ }^{3} \mathrm{H}\right]$ inositolphosphate accumulation was produced by TPA $\left(10^{-7} \mathrm{M}\right)$, whereas the same concentration of TPA inhibited carbachol- and gastrin-induced $\left[{ }^{3} \mathrm{H}\right]$ inositolphosphate accumulation by $42.4 \%$ and $39.0 \%$, respectively (Table 1). It is possible that the inhibition of NaF-induced polyphosphoinositide breakdown by TPA represents a part of the inhibition of carbachol- or gastrin-induced polyphosphoinositide hydrolysis by PKC. The post-receptor site where PKC exerts its inhibitory action in parietal cells is unknown at present. However, it has been reported that the $\alpha$-subunit of $\mathrm{Gi}$ is phosphorylated by PKC in a cell-free system, suggesting that the $\mathrm{G}$ protein itself is a site of action (11). On the other hand, Kikuchi et al. (12) have indicated that an unknown factor is involved in PKC-induced inhibition of polyphosphoinositide hydrolysis at a step

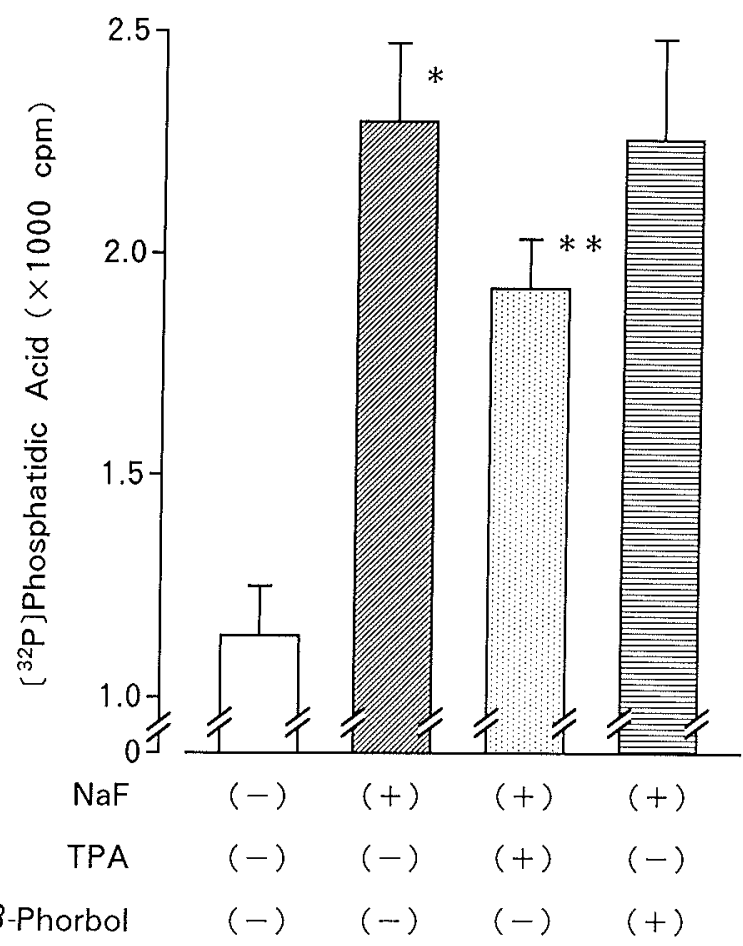

Fig. 4 Effects of TPA $\left(10^{-7} \mathrm{M}\right)$ and $4 \beta$-phorbol $\left(10^{-7} \mathrm{M}\right)$ on de novo synthesis of phosphatidic acid in canine parietal cells. After preincubation in the presence or absence of $10^{-7} \mathrm{M}$ TPA or $4 \beta$-phorbol for $2 \mathrm{~h}$, cells were incubated in phosphate-free buffer supplemented with $\left[{ }^{32} \mathrm{P}\right]$ orthophosphate $\left(5 \mu \mathrm{Ci} / 4 \times 10^{6}\right.$ cells $)$ in the presence or absence of $\mathrm{NaF}(10 \mathrm{mM})$ for $20 \mathrm{~min}$. Values are means $\pm S E M$ from four separate experiments, and each experiment consisted of duplicate samples. ${ }^{*} P<0.01$ vs control (without $\mathrm{NaF}$ ), ${ }^{* * *} * P<0.01$ vs $\mathrm{NaF}$ alone (without phorbol ester pretreatment)

between $\mathrm{G}$ protein and phospholipase $\mathrm{C}$.

Our previous and present studies raise the possibility that PKC exerts its inhibitory action on muscarinic- or gastrin-stimulated polyphosphoinositide hydrolysis at least at two sites, i.e. at muscarinic or gastrin receptor, and at a post-receptor site between $\mathrm{G}$ protein and phospholipase $\mathrm{C}$.

This work was supported by Grants-in-Aid for Scientific Research from the Ministry of Education, Science and Culture of Japan.

Received 3 September 1990; accepted 27 October 1990

\section{REFERENCES}

1. Batty I. R., Nahorski S. R. and Irvine R. F. (1985) Rapid formation of inositol 1, 3, 4, 5-tetrakisphosphate following 
muscarinic receptor stimulation of rat cerebral cortical slices. Biochem. J. 232, 211-215

2. Berridge M. J., Dawson R. M. C., Downes C. P., Heslop J, P. and IRvine R. F. (1983) Changes in the levels of inositol phosphates after agonist-dependent hydrolysis of membrane phosphoinositides. Biochem. J. 212, 473-482

3. Blackmore P. F., Bocckino S. B., Waynick L. E. and Exton J. H. (1985) Role of a guanine nucleotide-binding regulatory protein in the hydrolysis of hepatocyte phosphatidylinositol 4,5-bisphosphate by calcium-mobilizing hormones and the control of cell calcium. J. Biol. Chem. 260, 14477-14483

4. Brock T. A., Rittenhouse S. E., Powers C. W., Ekstein L. S., Gimbrone M. A. and Alexander R. W. (1985) Phorbol ester and 1-oleoyl-2-acetylglycerol inhibit angiotensin activation of phospholipase $\mathrm{C}$ in cultured vascular smooth muscle cells. J. Biol. Chem. 260, 14158-14162

5. Brown K. D., Blakeley D. M., Hamon M. H., Laurie M. S. and Corps A. M. (1987) Protein kinase C-mediated negative-feedback inhibition of unstimulated and bombesinstimulated polyphosphoinositide hydrolysis in Swissmouse 3T3 cells. Biochem. J. 245, 631-639

6. Chiba T., Fisher S. K., Agranoff B. W. and Yamada T. (1989) Autoregulation of muscarinic and gastrin receptors on gastric parietal cells. Amer. J. Physiol. 256, G356-G363

7. Chiba T., Fisher S. K., Park J., Seguin E. B., Agranoff B. W. and YAMADA T. (1988) Carbamoylcholine and gastrin induce inositol lipid turnover in canine gastric parietal cells. Amer. J. Physiol. 255, G99-G105

8. Chiba T., Yamaguchi A., Yamatani T., Nakamura A., Morishita T., Inui T., Fukase M., Noda T. and Fujita T. (1989) Calcitonin gene-related peptide receptor antagonist. human CGRP-(8-37). Amer. J. Physiol. 256, E331-E335

9. Guillon G., Mouillac B. and Marine-NoËlle B. (1986) Activation of polyphosphoinositide phospholipase $\mathrm{C}$ by fluoride in WRK1 cell membranes. FEBS Lett. 204, 183188

10. Jolles J., Schrama L. H. and Gispen W. H. (1981) Cal- cium-dependent turnover of brain polyphosphoinositides in vitro after prelabelling in vivo. Biochim. Biophys. Acta. 666, 90-98

11. Katada T., Gilman A. G., Watanabe Y., Bauer S. and JAKOBS K. H. (1985) Protein kinase C Phosphorylates the inhibitory guanine-nucleotide-binding regulatory component and apparently suppresses its function in hormonal inhibition of adenylate cyclase. FEBS Lett. 151. 431-437

12. Kikuchi A., IKeda K., Kozawa O. and TaKaI Y. (1987) Modes of inhibitory action of protein kinase $C$ in the chemotactic peptide-induced formation of inositol phosphates in differentiated human leukemic (HL-60) cells. $J$. Biol. Chem. 262, 6766-6770

13. LrTosCH I. (1987) Guanine nucleotide and $\mathrm{NaF}$ stimulation of phospholipase $\mathrm{C}$ activity in rat cerebral-cortical membranes. Biochem. J. 244, 35-40

14. Orellana S. A., Solski P. A. and Brown J. H. (1985) Phorbol ester inhibits phosphoinositide hydrolysis and calcium mobilization in cultured astrocytoma cells. J. Biol. Chem. 260, 5236-5239

15. Schacht J., Neale E. A. and Agranoff B. W. (1974) Cholinergic stimulation of phospholipid labelling from $\left[{ }^{32} \mathrm{P}\right]$ orthophoshate in guinea-pig cortex synaptosomes in vitro: subsynaptosomal localization. J. Neurochem. 23, 211218

16. SolL A. H. (1978) The actions of secretagogues on oxygen uptake by isolated mammlian parietal cells. J. Clin. Invest. 61, 370-380

17. Strnad C. F., Parente J. E. and Wong K. (1986) Use of fluoride ion as a probe for the guanine nucleotide-binding protein involved in the phosphoinositide-dependent neutrophil transduction pathway. FEBS Lett. 206, 20-24

18. Vicentini L. M., Di Virgilio F., Ambrosini A., Pozzan T. and Meldolesi J. (1985) Tumor promoter phorbol 12myristate, 13-acetate inhibits phosphoinositide hydrolysis and cytosolic $\mathrm{Ca}^{2+}$ rise induced by the activation of muscarinic receptors in $\mathrm{PC} 12$ cells. Biochem. Biophys. Res. Commun. 127, 310-317 